\title{
Positive effects of mesograzers on epiphytes in an eelgrass system
}

\author{
Sybill Jaschinski*, Ulrich Sommer \\ IFM-GEOMAR Leibniz Institute of Marine Sciences, Düsternbrooker Weg 20, 24105 Kiel, Germany
}

\begin{abstract}
Traditionally, consumer-prey interactions have been considered as purely negative, but herbivores may have positive effects on plants and their productivity. Grazing may enhance prey biomass-specific productivity by directly or indirectly reducing the competition for light, nutrients, and space. We studied the effect of 4 common mesograzers, the isopod Idotea baltica, the amphipod Gammarus oceanicus, and the gastropods Littorina littorea and Rissoa membranacea on epiphytes in an eelgrass Zostera marina L. system. Eelgrass was grown in laboratory mesocosms for a set of experiments manipulating mesograzer species identity, mesograzer density and nutrient concentration. We measured epiphyte biomass-specific productivity via incorporation of radioactive carbon. Herbivore effects on epiphyte photosynthetic capacity were strongly positive for $R$. membranacea, moderately positive for L. littorea and I. baltica and zero for G. oceanicus under low nutrient supply. Both gastropods increased the nitrogen content of epiphytes, especially the small $R$. membranacea, and enhanced epiphyte growth. The crustacean species did not increase epiphyte nutrient content, but I. baltica probably enhanced epiphyte productivity by removing the overstory of algal cells, and thus reducing competition for light, nutrients, and space. The positive effect of the 2 gastropod species disappeared under higher nutrient supply, implying the importance of nutrient limitation for this interaction. The positive effect of $I$. baltica remained at moderate grazer densities despite the higher nutrient concentrations.
\end{abstract}

KEY WORDS: Mutualism · Grazing $\cdot$ Periphyton $\cdot$ Herbivores $\cdot$ Littorina $\cdot$ Idotea $\cdot$ Gammarus $\cdot$ Rissoa . Nutrients

Resale or republication not permitted without written consent of the publisher

\section{INTRODUCTION}

Predation, competition, physical disturbances and physiological stress have been demonstrated to strongly influence the structure of marine ecosystems through negative interactions with community components (Bertness et al. 2001). However, recent research suggests that positive interactions play a more important role in organizing communities than previously assumed, and should be explicitly included in ecological theory (Bruno et al. 2003, Hay et al. 2004, Bulleri et al. 2008, Gross 2008). Facilitation in aquatic systems includes symbiotic relationships (as between corals and zooxanthellae, which provide the structure for one of the most diverse ecosystems worldwide), foundation species like seagrasses or kelp (which create 3- dimensional structure in an otherwise monotonous environment), and the so-called 'dangerous liaisons' (i.e. consumer-prey interactions and parasite-host mutualism; Hay et al. 2004).

Negative interactions which become positive in a community context are found in many consumer-prey interactions. Herbivorous chitons feed on encrusting coralline algae, which are resistant to most grazers. When the chitons are experimentally removed, the coralline algae are overgrown by epiphytic algae that attract parrotfish. These feed on epiphytes and the coralline host algae, causing far more damage to the coralline algae than the chitons (Littler et al. 1995). Territorial herbivorous damsel fish, which aggressively defend their algal mats, create patches of intermediate grazing intensity in coral reefs where algal species 
richness and evenness are increased compared to adjacent areas. The presence of this fish species also enhances algal productivity, although the mechanisms that cause this effect remain unclear (Hixon \& Brostoff 1996, Ceccarelli et al. 2001).

The stimulation of seagrass productivity by herbivory is another positive effect of consumer-prey interactions. Valentine et al. (1997) found that sea urchin grazing caused a $40 \%$ increase in the productivity of subtropical turtle grass. The sea urchins removed large parts of the seagrass biomass, but the simultaneous enhancement of productivity compensated this loss. Despite the strong grazing pressure, there was no significant reduction of seagrass biomass.

Nacken \& Reise (2000) even proposed that autumnal herbivory by brent geese and wigeon is essential to the survival of dwarf eelgrass. A field exclosure experiment showed that grazing caused a $45 \%$ reduction of biomass including rhizomes, which are important storage organs. In the next vegetation period however, the grazed sites had a significantly higher growth rate compared to former exclosure sites.

Small consumers (mesograzers) such as amphipods, isopods, and gastropods increase seagrass growth by removing epiphytes from its surface (Hughes et al. 2004). The resulting reduction in competition for light and nutrients can increase seagrass productivity, but the effect of mesograzers is species-specific (Duffy et al. 2001, Jaschinski \& Sommer 2008a). Overgrazing of eelgrass meadows by mesograzers is known, but is believed to be a rare incident occurring only under high mesograzer densities (Fredriksen et al. 2004). Seagrasses provide mesograzers with food (epiphytes), a structure to live on, and a refuge from predation. The strong positive interactions between mesograzers and seagrasses are supposed to be fundamental for the health and continued existence of these ecologically and economically important ecosystems.

In addition to this mutualism, mesograzers may increase the photosynthetic capacity (production per biomass) of their prey: the algal assemblage growing on seagrasses or other substrates. The increase in the photosynthetic capacity of periphyton by small invertebrate grazers is thought to be caused by 2 mechanisms. (1) The removal of the overstory of cells and the destruction of the boundary layer that impedes nutrient diffusion reduce the competition for space, light and nutrients and are likely to boost the biomassspecific productivity of the algae (McCormick \& Stevenson 1991). (2) Sloppy feeding and excretory products of grazers may directly increase the availability of nutrients (Grimm 1988, Mulholland et al. 1991, Kahlert \& Baunsgaard 1999). Some experiments have shown a positive effect of grazers on periphyton nutrient content (Hunter \& Russel-Hunter 1983, Rosemond et al.
1993, Hillebrand \& Kahlert 2001, Hillebrand et al. 2004), but only 1 study has directly measured the photosynthetic capacity of a marine epilithic community (Kaehler \& Froneman 2002). However, the enhanced epilithion productivity observed by Kaehler \& Froneman (2002) was not caused by the mechanisms described above, but via a change in community composition: the remaining algae assemblage was composed of very productive species.

We manipulated the abundance of 4 mesograzers in experimental eelgrass systems to test their effect on epiphyte nutrient content and photosynthetic capacity. The isopod Idotea baltica (hereafter Idotea), the amphipod Gammarus oceanicus (hereafter Gammarus), and the 2 gastropod species Littorina littorea (hereafter Littorina) and Rissoa membranacea (hereafter Rissoa) are potentially dominant grazers in eelgrass systems. All 4 species are known to graze on epiphytes, but they have different feeding modes (crustaceans = 'lawn-mower', gastropods = 'bulldozer': Sommer 1999) and vary in their selectivity. Seasonal abundance patterns differ strongly for the studied species (S. Jaschinski unpubl. data), implying that their impact on epiphytes also varies in the course of the year. Additionally, we varied nutrient supply to determine if the hypothesized positive impacts of mesograzers on epiphytes would persist under eutrophic conditions.

\section{MATERIALS AND METHODS}

Experimental design. We conducted 7 mesocosm experiments to test the impact of 4 common mesograzer species on the nutrient content and photosynthetic capacity of epiphytes in an eelgrass system under ambient and high nutrient supply. The experiments took place in summer 2002 (one after the other from June to September). A preliminary field study had shown that the qualitative and quantitative composition of epiphytes is relatively constant during this period. Each experiment included 4 treatments: a grazer-free control and low, moderate and high abundances of 1 grazer species (Table 1). Experimental aquaria were divided into 4 compartments each, and treatments were assigned to compartments according to a randomized block design. There were 6 aquaria, i.e. 6 independent replicates of each experimental treatment. Mesograzer abundances were chosen based on species-specific numerical summer densities $\mathrm{m}^{-2}$ according to monitoring data for eelgrass associated macrofauna in the Kiel Bight (4 stations, 1997 to 2001). The average of all stations and years was used as the moderate density for the 4 consumer species. Half of this abundance represented the low density 
Table 1. Grazer abundances in all experiments. Gammarus, Idotea and Littorina were about $10 \mathrm{~mm}$ long, Rissoa $6 \mathrm{~mm}$. Treatments with the same biomass are shown in bold. mod: moderate; AFDM: ash-free dry mass; ind.: individuals

\begin{tabular}{|c|c|c|c|c|c|c|}
\hline \multirow[t]{2}{*}{ Grazer } & \multicolumn{3}{|c|}{ Density (ind. $\mathrm{m}^{-2}$ ) } & \multicolumn{3}{|c|}{ Biomass $\left(\mathrm{g}\right.$ AFDM m ${ }^{-2}$ ) } \\
\hline & Low & Mod & High & Low & Mod & High \\
\hline Gammarus & 80 & 160 & 320 & 0.24 & 0.48 & 0.96 \\
\hline Idotea & 128 & 256 & 512 & 0.48 & 0.96 & 1.92 \\
\hline Littorina & 64 & 128 & 256 & 0.96 & 1.92 & 3.84 \\
\hline Rissoa & 320 & 640 & 1280 & 0.24 & 0.48 & 0.96 \\
\hline
\end{tabular}

treatment, and we doubled the average in the high density treatment.

The experiments took place in a constant temperature chamber. The 6 replicate aquaria were $125 \mathrm{l}$ each $(50 \mathrm{~cm} \times 50 \mathrm{~cm} \times 50 \mathrm{~cm})$, and were divided into $4 \mathrm{com}-$ partments with $1 \mathrm{~mm}$ metal mesh, resulting in 24 'mesocosms' of $25 \mathrm{~cm} \times 25 \mathrm{~cm} \times 50 \mathrm{~cm}$. This corresponds to the minimum mesocosm size recommended for experiments with seagrass (Short et al. 2001). Summer conditions found in eelgrass systems in the western Baltic Sea were established concerning light, temperature and nutrients. The aquaria were illuminated by HQI-lamps with a $16 \mathrm{~h}$ day and $8 \mathrm{~h}$ night cycle. The light intensity was $100 \mu \mathrm{mol} \mathrm{m} \mathrm{m}^{-2} \mathrm{~s}^{-1}$ at the water surface. The temperature in the constant temperature chamber was set to $17^{\circ} \mathrm{C}$. However, due to a warming effect of the lamps, the water temperature in the aquaria was slightly higher $\left(18.6 \pm 0.3{ }^{\circ} \mathrm{C}\right)$. Sandfiltered brackish deep water from the Kiel Fjord (salinity: $14.1 \pm 2.2$ PSU) was used and additionally filtered with a $0.8 \mu \mathrm{m}$ membrane filter to avoid contamination with plankton species. Nutrient concentrations in the 4 experiments under ambient nutrient conditions were $5 \mu \mathrm{mol} \mathrm{l} \mathrm{l}^{-1}$ nitrate and $0.25 \mu \mathrm{mol} \mathrm{l^{-1 }}$ phosphate. In the 3 experiments under higher nutrient supply the values were 3-fold enriched. Silicate levels were high $\left(14.5 \mu \mathrm{mol} \mathrm{l} \mathrm{l}^{-1}\right)$.

Continuous water circulation was created using pumps and the water was exchanged (up to $90 \%$ of the total volume) every day. Periphyton growing on the walls of the aquaria was removed every day before the water exchange.

The mesocosms were filled with $1 \mathrm{~mm}$-sieved homogenized sediment ( $5 \mathrm{~cm}$ depth), which consisted mainly of fine sand with low organic content. After 24 h, 20 freshly harvested eelgrass shoots were planted in each mesocosm (320 shoots $\mathrm{m}^{-2}$, the average summer abundance in the Kiel Fjord). Only shoots with $\geq 4$ leaves were selected; the average length of shoots was $40 \mathrm{~cm}$. We measured the initial biomass of epiphytes (chl a) on 10 eelgrass shoots in each experiment. There was no significant difference in initial epi- phyte biomass between experiments. On the following day, the mesocosms were stocked with grazers. All experimental material was collected at Falkenstein Beach in the inner Kiel Fjord, Germany $\left(54^{\circ} 21^{\prime} \mathrm{N}\right.$, $\left.10^{\circ} 9^{\prime} \mathrm{E}\right)$. The experiment was terminated after $10 \mathrm{~d}$. At this time, the eelgrass was harvested, placed in plastic bags and stored frozen until further processing.

A preliminary experiment had shown that the optimal experimental duration was $10 \mathrm{~d}$, because overgrazing, cannibalism and reproduction occurred soon after $10 \mathrm{~d}$ in the crustacean treatments.

Epiphyte productivity. Primary productivity estimates based on ${ }^{14} \mathrm{C}$ measurements were carried out on the last day of the experiment. Four eelgrass shoots were randomly selected from each mesocosm, and the mid section of each shoot $(10 \mathrm{~cm})$ was transferred into a transparent Nalgene plastic bottle containing $250 \mathrm{ml}$ seawater $(0.2 \mu \mathrm{m}$ filtered). Only shoots with 4 leaves were used. After inoculation with $26.4 \mu \mathrm{Ci}{ }^{14} \mathrm{C}$ $\mathrm{Na}_{2} \mathrm{CO}_{3}, 3 \mathrm{~h}$ incubations were carried out under experimental conditions (between 10:00 and 14:00 h). One bottle out of each mesocosm was wrapped up in aluminium foil and used for dark incubation. After incubation, all eelgrass shoots were placed in plastic bags and stored frozen until further processing.

We measured water temperature, salinity and $\mathrm{pH}$ of the used seawater to calculate available carbon via alkalinity according to Buch (1945). A standard carbon concentration can be used in marine water with an average salinity of 35, but the available carbon must be calculated via alkalinity in brackish and fresh-water.

Epiphytes were separated from the eelgrass leaves by carefully scraping the blades using a plastic scraper and a scalpel, and then transferred into small amounts of filtered sea water. This suspension was filtered on pre-weighed $0.2 \mu \mathrm{m}$ membrane filters (cellulose nitrate, Sartorius). The filters were dried $\left(48 \mathrm{~h}, 60^{\circ} \mathrm{C}\right)$ and weighted to calculate dry weight. Then the filters were transferred into scintillation vials containing $10 \mathrm{ml}$ Lumagel (Perkins Elmer). Radioactivity was measured in a Liquid Scintillation Counter. All counts were corrected for background and counting efficiency.

Productivity was calculated as follows:

$$
\operatorname{mg~C}\left(\mathrm{g} \mathrm{DW}^{-1} \mathrm{~h}^{-1}=\frac{\mathrm{dpm}_{1} \times{ }^{12} \mathrm{CO}_{2} \times 1.06}{\mathrm{dpm}_{2} \times \mathrm{DW} \times t}\right.
$$

where $\mathrm{dpm}_{1}$ is the activity (decay per minute) of the samples minus the activity in the dark incubation as correction for non-photosynthetic uptake of ${ }^{14} \mathrm{C}, \mathrm{dmp}_{2}$ is the activity of the isotope added to the bottles and ${ }^{12} \mathrm{CO}_{2}$ is the $\mathrm{mg}$ available inorganic carbon. The factor 1.06 is a correction for isotope discrimination; DW is the dry weight of the epiphyte sample, and $t$ is the length of the incubation period in hours (Penhale 1977). 
Elemental composition. Two eelgrass shoots from each mesocosm were washed in filtered seawater to remove detritus and faecal pellets. Observations with a dissecting microscope after the cleaning procedure showed the successful removal of unwanted material. Epiphytes were carefully scraped from the eelgrass blades using a plastic scraper and a scalpel and transferred to small amounts of filtered sea water. This suspension was filtered on precombusted Whatman GF/F filters $\left(450^{\circ} \mathrm{C}, 24 \mathrm{~h}\right)$. After drying $\left(24 \mathrm{~h}, 60^{\circ} \mathrm{C}\right)$ the samples were stored in a desiccator until combustion in a $1500 \mathrm{~N} \mathrm{CHN}$-analyser (Fisons Instruments) to measure $\mathrm{C}$ and $\mathrm{N}$ content. The $\mathrm{C}: \mathrm{N}$ ratios were calculated in molar units.

Chlorophyll $a$ and phaeophytin. We measured the photosynthetic pigment chlorophyll $a$ and its degradation product phaeophytin and used the proportion of phaeophytin as a proxy for the proportion of dead and senescent cells in the epiphyte assemblages. Six eelgrass shoots were randomly selected from each mesocosm. Epiphytes were carefully scraped from the eelgrass leaves and collected on GF/F filters as described in the previous section. Pigment analyses with HPLC, carried out on scraped eelgrass blades and epiphytes, indicated that removal efficiency by scraping was up to $99 \%$. Chlorophyll $a$ and phaeophytin concentrations were calculated according to Lorenzen (1967). The cleaned eelgrass blades were dried to a constant weight $\left(48 \mathrm{~h}, 60^{\circ} \mathrm{C}\right)$, and subsequently combusted for $8 \mathrm{~h}$ at $540^{\circ} \mathrm{C}$ to determine the ash-free dry mass (AFDM). The eelgrass surface area was calculated using the formula surface $\left(\mathrm{mm}^{2}\right)=$ AFDM $(\mathrm{g}) \times$ $588.88\left(R^{2}=0.97\right)$, determined by measuring and weighing 100 eelgrass shoots. All epiphytic chlorophyll a and phaeophytin concentrations were normalized to unit eelgrass leaf surface area.

Comparative effects. To compare the per biomass effect of the 4 studied grazer species on epiphyte photosynthetic capacity and nitrogen content, grazer effects on epiphytes and eelgrass were calculated as the raw difference between control and grazer treatments with the same biomass level (0.96 mg AFDM m ${ }^{-2}$; Table 1).

Statistics. We performed 1-way ANOVAs to analyse the influence of mesograzer abundance on epiphytes biomass-specific productivity and $\mathrm{C}: \mathrm{N}$ for each independent experiment. We initially analysed the data using randomized block ANOVAs, in which the different abundances were considered fixed factors. The block effect was non-significant in all analyses, therefore the block factor was ignored and the data were reanalysed with a 1-way ANOVA. Differences between treatments were tested with Tukey's test.

We calculated the effect size (Hedges' $d$ ) of mesograzer impact on epiphyte biomass-specific productivity and the C:N ratio for the treatments with the same mesograzer biomass.

This effect measure represents the standardized difference between treatment and control means divided by the combined SD of both treatments (Gurevitch \& Hedges 1993).

\section{RESULTS}

\section{Epiphyte photosynthetic capacity}

With the exception of Gammarus, epiphyte biomass-specific productivity $\mu \mathrm{g} C$ (mg DW epiphytes) $)^{-1}$ $\mathrm{h}^{-1}$ increased significantly with the presence of grazers (Fig. 1, Table 2). Rissoa had the strongest effect on epiphyte biomass-specific productivity; even medium abundances of this species significantly enhanced this parameter, and high abundances of this species nearly doubled epiphyte productivity compared to controls. Idotea and Littorina showed significant effects only in the high abundance treat-
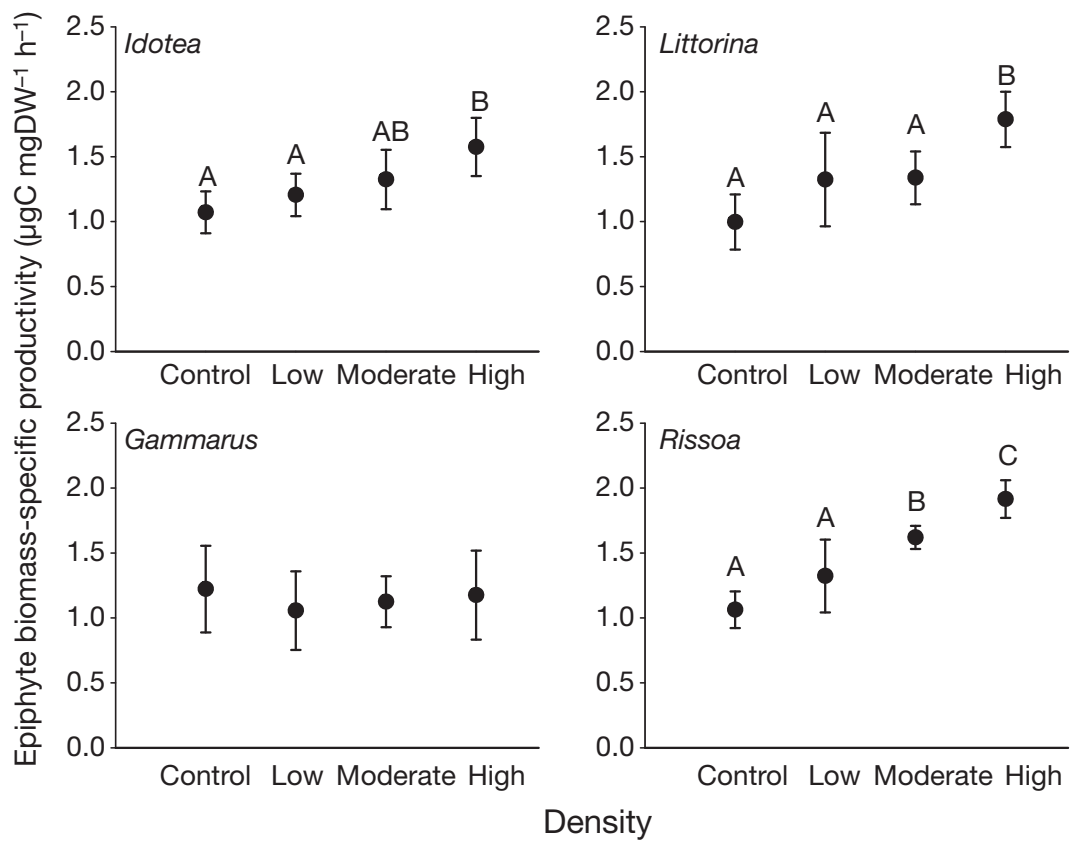

Fig. 1. Effect of grazer abundance on epiphyte biomass-specific productivity (means $\pm \mathrm{SD}$ ) under low nutrient conditions. Capital letters indicate significant differences between treatments 
ments. Epiphyte biomass-specific productivity increased by 47 and $80 \%$ in the high abundance treatments of Idotea and Littorina. Gammarus had no significant impact on epiphyte photosynthetic capacity.

The effect on epiphyte biomass-specific productivity differed substantially among the 4 grazers when the treatments with the same grazer biomass are compared (Fig. 3A). The magnitude of the effect was approximately equally positive for Idotea (Hedges' $d=1.2$ ) and Littorina ( $d=$ 1.0). Rissoa had the highest positive effect on epiphyte biomass-specific productivity ( $d=5.5$ ) and Gammarus had no effect at all $(d=-0.1$; not significantly different from zero).

\section{Epiphyte C:N}

Initial values of epiphyte $\mathrm{C}: \mathrm{N}$ ratio ranged from 12.1 to 12.5 indicating a deficiency of nitrogen in summer. Epiphyte $C: N$ values from 7.5 to 8.9 were observed under higher nutrient conditions in spring and autumn (Jaschinski \& Sommer 2008a). In the experiments with Idotea and Gammarus, the initial values remained basically unchanged. In contrast, Littorina and Rissoa had a significant positive effect on the nitrogen content of epiphytes (Fig. 2, Table 2).

Rissoa reduced the $\mathrm{C}: \mathrm{N}$ ratio most strongly $(d=$ -11.8) in the treatments with the same grazer biomass, whereas the impact of Littorina $(d=-1.4)$ was 10 times
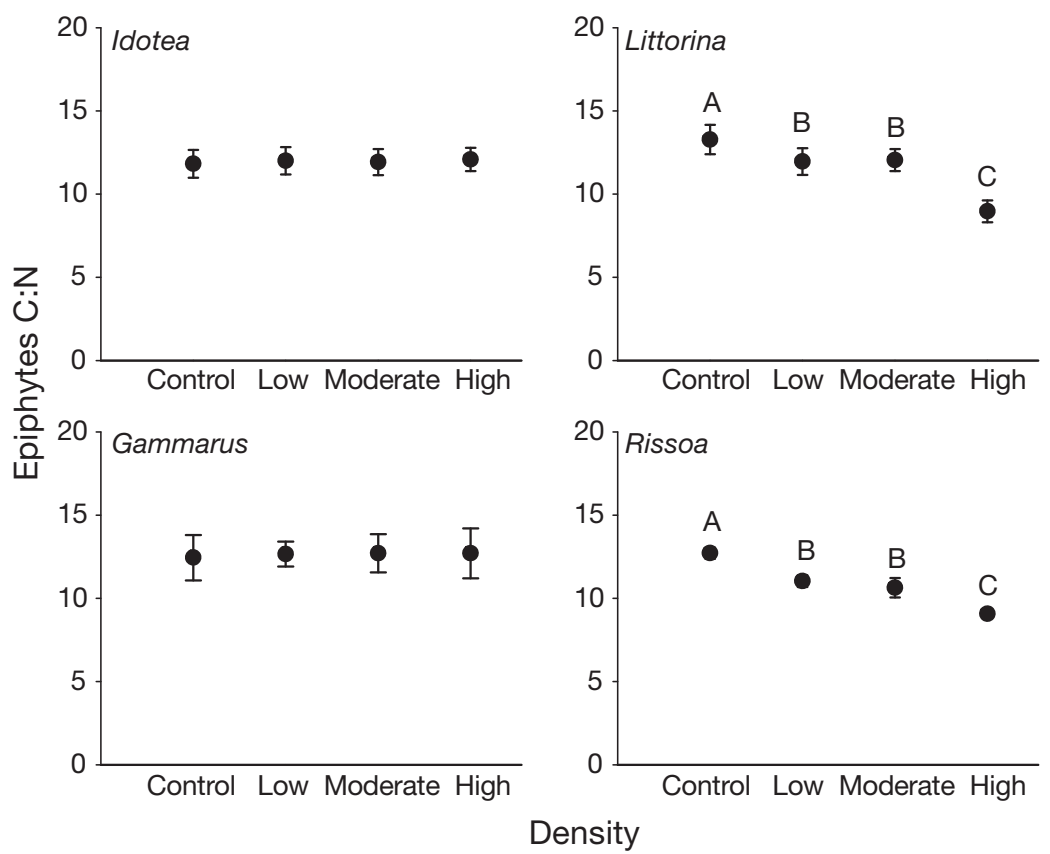

Fig. 2. Effect of grazer abundance on epiphyte C:N (means \pm SD) under low nutrient conditions. Capital letters indicate significant difference between treatments

smaller (Fig. 3B). Gammarus and Idotea exerted no significant effect on the C:N ratio $(d=0.1$; not significantly different from zero).

\section{Dead and senescent algal cells}

The proportion of phaeophytin was not significantly different in grazer treatments and controls in the 4 experiments. Phaeophytin accounted for 17 to $23 \%$ of the algal chlorophyll a.

Table 2. Results of the ANOVAs of mesograzer impact on epiphyte photosynthetic capacity and C:N. Significant effects on epiphyte photosynthetic capacity were always positive, the significant effects on $\mathrm{C}: \mathrm{N}$ always decreased this ratio because of increasing nitrogen concentrations

\begin{tabular}{|c|c|c|c|c|c|c|c|}
\hline Grazer & Density & $\begin{array}{l}\text { Epiphyte } \\
\text { control }\end{array}$ & $\begin{array}{c}\text { Productivity } \\
\text { low }\end{array}$ & $\begin{array}{l}\text { (p-level) } \\
\text { moderate }\end{array}$ & $\begin{array}{l}\text { Epiphyte } \\
\text { control }\end{array}$ & $\begin{array}{l}\mathrm{C}: \mathrm{N} \\
\text { low }\end{array}$ & $\begin{array}{l}\text { (p-level) } \\
\text { moderate }\end{array}$ \\
\hline \multirow[t]{3}{*}{ Gammarus } & Low & 0.773 & & & 0.990 & & \\
\hline & Moderate & 0.941 & 0.978 & & 0.981 & 0.999 & \\
\hline & High & 0.993 & 0.898 & 0.991 & 0.982 & 0.999 & 0.999 \\
\hline \multirow[t]{3}{*}{ Idotea } & Low & 0.646 & & & 0.978 & & \\
\hline & Moderate & 0.150 & 0.724 & & 0.995 & 0.999 & \\
\hline & High & 0.002 & 0.020 & 0.159 & 0.938 & 0.999 & 0.986 \\
\hline \multirow{3}{*}{ Littorina } & Low & 0.154 & & & 0.032 & & \\
\hline & Moderate & 0.131 & 0.999 & & 0.048 & 0.997 & \\
\hline & High & $<0.001$ & 0.025 & 0.030 & $<0.001$ & $<0.001$ & $<0.001$ \\
\hline \multirow[t]{3}{*}{ Rissoa } & Low & 0.088 & & & $<0.001$ & & \\
\hline & Moderate & $<0.001$ & 0.042 & & $<0.001$ & 0.335 & \\
\hline & High & $<0.001$ & $<0.001$ & 0.044 & $<0.001$ & $<0.001$ & $<0.001$ \\
\hline
\end{tabular}



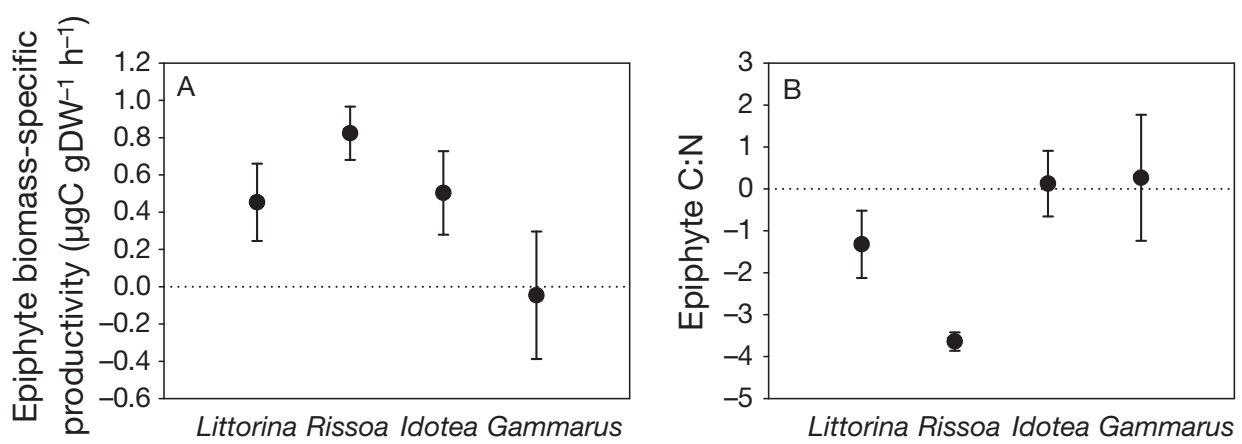

Fig. 3. Per biomass effects of grazer species on (A) epiphyte biomass-specific productivity and (B) epiphyte C:N. Shown are the raw, arithmetic differences between grazer treatments and grazer-free controls corrected for biomass (g AFDM)

Table 3. Effects of mesograzers on epiphyte biomass $\mu g$ chl a $\left(\mathrm{cm}^{2} \text { eelgrass }\right)^{-1} \mathrm{~d}^{-1}$. Shown are the removal of biomass via grazing (negative effect) and the increase in biomass caused by indirect grazing effects (positive effect)

\begin{tabular}{|lccc|}
\hline Grazer & Density & $\begin{array}{c}\text { Positive } \\
\text { effect }\end{array}$ & $\begin{array}{c}\text { Negative } \\
\text { effect }\end{array}$ \\
\hline Idotea & Low & 0.0008 & 0.0057 \\
& Moderate & 0.0009 & 0.0096 \\
Littorina & High & 0.0016 & 0.0104 \\
& Low & 0.0007 & 0.0107 \\
& Moderate & 0.0005 & 0.0163 \\
Rissoa & High & 0.0003 & 0.0216 \\
& Low & 0.0011 & 0.0042 \\
& Moderate & 0.0012 & 0.0119 \\
& High & 0.0011 & 0.0151 \\
\hline
\end{tabular}

\section{Comparison of positive and negative effects of grazers on epiphyte biomass}

To compare the positive and negative effects of mesograzers on epiphyte biomass we calculated the removal by grazing and the increase caused by indirect grazing effects $\mu \mathrm{g}$ chl a $\left(\mathrm{cm}^{2} \text { eelgrass }\right)^{-1} \mathrm{~d}^{-1}$, assuming that these processes were constant during the experiment. Positive and negative effects varied between mesograzer species and density (Table 3). The importance of positive effects in comparison to negative effects changed accordingly (Fig. 4). Rissoa increased the biomass of epiphytes by $\sim 26 \%$ compared to the negative impact of this mesograzer at low grazer densities. This percentage decreased to $7 \%$ at high densities. Littorina caused a smaller percentage increase, ranging from $7 \%$ at low density of this grazer to $1 \%$ at high density. Idotea had an intermediate positive impact ( 13\%).

\section{Grazer effect on epiphyte photosynthetic capacity and $C: N$ ratio under high nutrient supply}

Epiphyte biomass-specific productivity only increased significantly in the presence of moderate den-

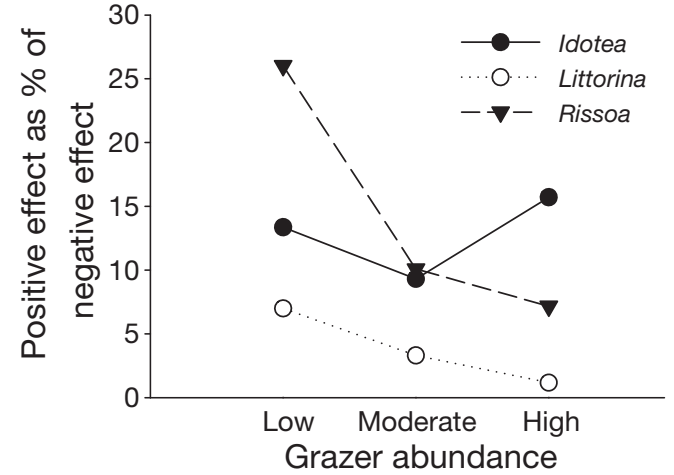

Fig. 4. Increase in epiphyte biomass caused by positive grazing effects shown as percentage of the decrease in epiphyte biomass by grazing; both effects were calculated as $\mu \mathrm{g}$ chl a $\left(\mathrm{cm}^{2} \text { eelgrass }\right)^{-1} \mathrm{~d}^{-1}$

sities of Idotea ( $\mathrm{p}=0.040)$ under high nutrient supply (Fig. 5). Furthermore, we found a significant decrease in epiphyte biomass-specific productivity between the moderate and high density treatment of Idotea $(\mathrm{p}<$ 0.001). The presence of Littorina and Rissoa had no effect on epiphyte photosynthetic capacity. No grazer species had a significant impact on epiphyte C:N ratio.

\section{DISCUSSION}

In contrast to the traditional view, according to which the interaction of consumers and their plant prey has been regarded as a unidirectional negative relationship, a growing number of studies emphasize the importance of positive effects of grazing (Sterner 1986, Kahlert \& Baunsgaard 1999, Hay et al. 2004, Hillebrand et al. 2004). Our study supports the hypotheses that consumers can enhance the biomass-specific productivity of primary producers. Consumer effects on epiphyte biomass-specific productivity were strongly positive for Rissoa, moderately positive for Littorina and Idotea and essentially zero for Gammarus. 


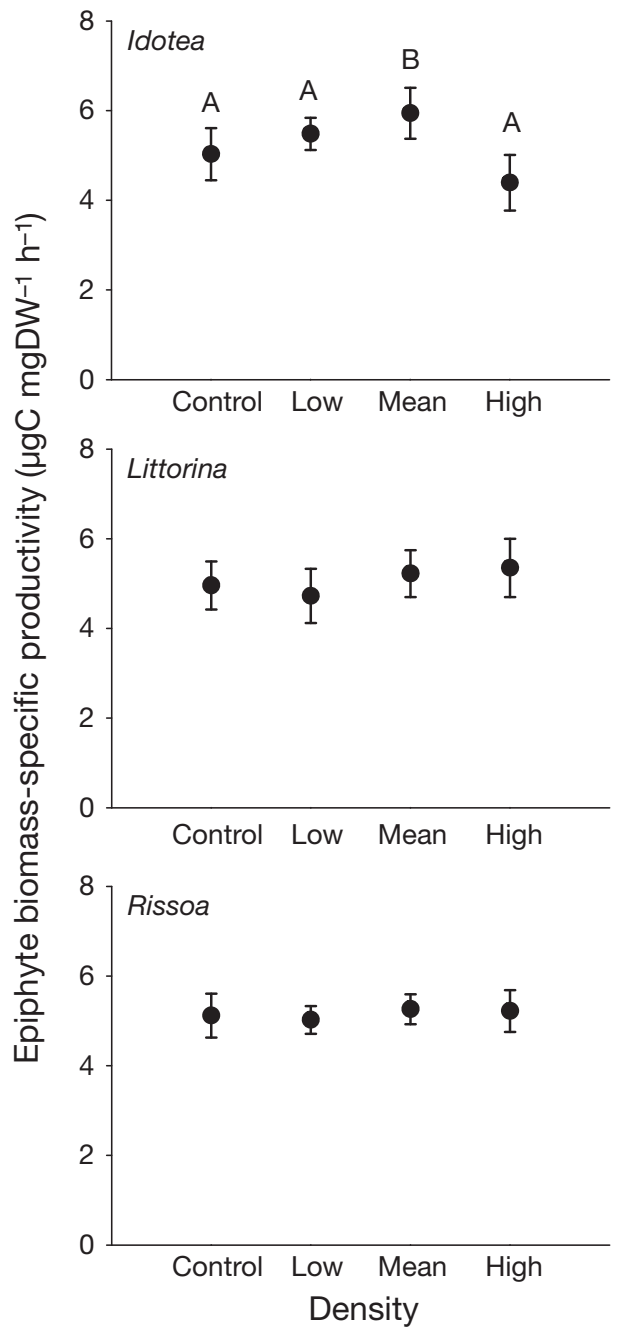

Fig. 5. Effect of grazer abundance on epiphyte biomassspecific productivity (means $\pm \mathrm{SD}$ ) under high nutrient conditions. Capital letters indicate significant differences between treatments

It has previously been assumed that grazers can influence the photosynthetic capacity of biofilms in a positive way by directly or indirectly reducing competition for nutrients (McCormick \& Stevenson 1991, Mulholland et al. 1991, Kahlert \& Baunsgaard 1999, Hillebrand \& Kahlert 2001). Marine herbivores can provide their plant prey with nitrogen by direct excretion of mainly ammonium and by production of faecal pellets. The strong negative impact of Rissoa and Littorina on epiphyte $\mathrm{C}: \mathrm{N}$ ratios supports the assumption that, in contrast to the tested crustaceans, gastropods enhanced the photosynthetic capacity of epiphytes via excretory products in our study. Especially in the Rissoa treatments, many faecal pellets were observed, which adhered to the epiphyte assemblages. Apparently, this had immediate consequences for the nutrient availability in adjacent algal patches. Epiphytes under Rissoa grazing had the strongest increase in nitrogen content compared to ungrazed algal assemblages. Nitrogen is the limiting nutrient in epiphytic assemblages on eelgrass from late spring to autumn (Jaschinski \& Sommer 2008b). The use of nutrient ratios to indicate nutritive status of microalgae is commonly used for phytoplankton, but the interpretation of such data for periphyton has to be treated with caution because detritus and heterotrophic elements could influence the nutrient ratios. However, microscopic observations showed that neither changes in detritus and heterotrophs nor changes in algal composition compromised our data.

A positive effect of grazers on nutrient content of microalgae has been previously reported in freshwater systems (Rosemond et al. 1993, Hillebrand et al. 2004, Liess et al. 2006) and in 1 intertidal periphyton community (Hunter \& Russel-Hunter 1983). All studies used gastropods including Littorina as grazers, which live in close association with their food sources. The more mobile crustacean grazers have the potential to supply a significant amount of nitrogen via ammonium excretion to the plant community (Taylor \& Rees 1998), but experimental evidence on the importance of nutrient recycling via grazing so far exists only for slow moving or sessile organisms like gastropods, bryozoans and barnacles (Hurd et al. 1994, Williamson \& Rees 1994). In our experiments, sinking faecal pellets of Idotea and Gammarus may have enriched the microphytobenthos; the nitrogen content of eelgrass was not influenced by the different treatments (S. Jaschinski unpubl. data). Our experimental design did not allow testing for potential ammonium enrichment in the water. However, the dispersal and dilution of waste products is thought to restrict the importance of this mechanism in free-swimming mesograzers (Probyn \& Chapman 1983).

Gastropod and crustacean mesograzers differ in their feeding mode. Idotea and Gammarus are generally considered to reduce the microalgal community homogenously ('lawn-mower' type of grazer), whereas Littorina and Rissoa produce a feeding trail by scraping the surface with their radula ('bulldozer' type of grazer, Sommer 1999). The taenioglossan radula of the studied gastropods enables these species to completely remove the epiphytic layer on eelgrass leaves (van Montfrans et al. 1982). These differences influence the mesograzer effect on epiphyte photosynthetic capacity.

The difference in the influence on epiphyte biomassspecific productivity between Idotea (positive effect) and Gammarus (no effect) strengthens the conjecture that the removal of the biofilm's canopy layer, and thus reducing competition for light and space, also played an important role in the enhancement of the photosynthetic capacity of epiphytes by mesograzers. The dif- 
ferent selectivity of these mesograzers influences their effect on epiphyte community composition and structure. Epiphyte composition was clearly dominated by diatoms, which constituted 74 to $99 \%$ of epiphyte biovolume, but small filamentous algae-mostly the red alga Acrochaetium secundatum and the brown alga Myrionema sp.-were also present. The diatoms showed a high level of differentiation in growth form and cell size. The most important prostrate diatom species was the strongly adhering Cocconeis scutellum, stalked forms mainly consisted of Licmophora species. The only tube-living diatom was Berkeleya rutilans, and diatom chains were represented by Melosira nummuloides and Grammatophora marina. Idotea fed on diatom chains, filamentous algae, and stalked diatoms; whereas Gammarus is only capable of removing some of the filamentous growth forms (S. Jaschinski et al. unpubl.). The stronger effect of Idotea on the structure of the algal assemblage might have mediated the availability of light and space to the epiphyte community. Self-shading can reduce primary production in lower layers in ungrazed periphyton communities and thus decrease the photosynthetic capacity of the assemblage (Brush \& Nixon 2002).

The removal of senescent or dead algal cells does not seem to be important for the positive effect of grazing on epiphyte photosynthetic capacity. The proportion of phaeophytin, the degradation product of chlorophyll $a$, was not significantly different in consumer and control treatments. Phaeophytin accounted for 17 to $23 \%$ of epiphyte chlorophyll a. Lamberti and Resh (1983) found similar values for stream periphyton under caddisfly grazing. This consumer likewise fed indiscriminately with respect to living versus dead algae.

Several freshwater studies reported an increase in periphyton photosynthetic capacity mediated by consumers (Lamberti \& Resh 1983, Lamberti et al. 1987, Hill \& Harvey 1990), but 2 experiments found a reduction of chlorophyll-specific productivity. The consumers had created a community dominated mainly by grazing-resistant species, which as a trade-off had relatively low growth rates (Rosemond et al. 1993, Hill et al. 1992). We found a similar trend for Idotea grazing in the experiment with higher nutrient supply. High abundances of Idotea reduced epiphyte photosynthetic capacity, probably via preferentially feeding on the fast-growing chain-forming diatom Melosira nummuloides, which profited most from nutrient enrichment. This change in epiphyte composition via grazing had a negative effect on the photosynthetic capacity of the algal community.

We clearly showed an enhancement of epiphyte productivity via grazing, but the positive effects did not compensate for the consumptive losses: i.e. the presence of mesograzers did not increase epiphyte biomass
(Jaschinski \& Sommer 2008a). Nevertheless, estimations of positive and negative grazing effects on epiphyte biomass showed that the promotion of epiphyte productivity can counterbalance up to $26 \%$ of biomass losses (Rissoa). The positive effect of Idotea on epiphyte biomass was only half as high $(\sim 13 \%)$, and Littorina produced the smallest positive effect (mean $4 \%$ ). Although these data should be treated with caution, our results imply that beneficial effects of mesograzers may play a relevant role in optimizing plant productivity as models predict. Thus, the effect of mesograzers on epiphytes can be considered at least partly mutualistic (de Mazancourt et al. 1998). However, the importance of this interaction depends on the nutrient supply of the community. The positive effect of the gastropods on epiphyte nitrogen content, and accordingly epiphyte productivity, found under relatively low nutrient conditions disappeared under higher nutrient supply. This is in good accordance with a model showing that the positive effect of herbivores depends on the strength of plant nutrient limitation (de Mazancourt et al. 1998). Idotea enhanced epiphyte photosynthetic capacity at moderate densities despite the nutrient enrichment, implying that the supposed removal of the overstory of cells, and thus the increased light intensities reaching deeper layers, may be of importance even in more eutrophic systems.

In conclusion, the positive interactions between mesograzers and their periphyton prey depend on consumer identity, grazing pressure and environmental conditions. Recent studies found that species-level characteristics of mesograzers had important effects in eelgrass systems (Duffy et al. 2001, Jaschinski \& Sommer 2008a). Our study showed that functional diversity of mesograzers is also an issue concerning the potential positive effects on epiphyte productivity, with possible consequences for the functioning of ecosystems as the dominance of grazer changes with season and location. Higher nutrient supply via direct or indirect consumer effects seems to be more important in nutrient poor conditions, the reduction of competition for space and/or light may additionally enhance the productivity under higher nutrient supply when nutrients are not limiting.

Acknowledgements. We are grateful to S. Flöder and 4 anonymous reviewers for critical reading of the MS and helpful comments, and to numerous scuba divers for supplying the eelgrass necessary for our experiments. Financial support was provided by the German Research Foundation (So $145 / 20$ ). We declare that our experiments comply with the current laws of Germany.

\section{LITERATURE CITED}

Bertness MD, Gaines SD, Hay ME (eds) (2001) Marine community ecology. Sinauer, Sunderland, MA 
Bruno JF, Stachowicz JJ, Bertness MD (2003) Inclusion of facilitation into ecological theory. Trends Ecol Evol 18:119-125

Brush MJ, Nixon SW (2002) Direct measurements of light attenuation by epiphytes on eelgrass Zostera marina. Mar Ecol Prog Ser 238:73-79

Buch K (1945) Kolsyrejämnvikten i Baltiska Havet. Fennia 68:5

> Bulleri F, Bruno JF, Benedetti-Cecchi L (2008) Beyond competition: Incorporating positive interactions between species to predict ecosystem invasibility. PLoS Biol 6:e162. doi:10.1371/journal.pbio.0060162

Ceccarelli DM, Jones GP, McCook LJ (2001) Territorial damselfish as determinants of the structure of benthic communities on coral reefs. Oceanogr Mar Biol Annu Rev 39:355-389

de Mazancourt C, Loreau M, Abbadie L (1998) Grazing optimization and nutrient cycling: when do herbivores enhance plant production. Ecology 79:2242-2252

Duffy JE, MacDonald KS, Rhode JM, Parker JD (2001) Grazer diversity, functional redundancy, and productivity in seagrass beds: an experimental test. Ecology 82:2417-2434

Fredriksen S, Christie H, Boström C (2004) Deterioration of eelgrass (Zostera marina L.) through destructive grazing by the gastropod Rissoa membranacea (J. Adams). Sarsia 89:218-222

Grimm NB (1988) Role of macroinvetebrates in nitrogen dynamics of a desert stream. Ecology 69:1884-1893

Gross K (2008) Positive interactions among competitors can produce species-rich communities. Ecol Lett 11:929-936

Gurevitch J, Hedges LV (1993) Meta-analysis: combining the results of independent experiments. In: Scheiner SM, Gurevitch J (eds) Design and analysis of ecological experiments. Chapman \& Hall, London, p 378-398

> Hay ME, Parker JD, Burkepile DE, Caudill CC, Wilson AE, Hallinan ZP, Chequer AD (2004) Mutualism and aquatic community structure: the enemy of my enemy is my friend. Annu Rev Ecol Syst 35:175-197

Hill WR, Harvey CJ (1990) Periphyton responses to higher trophic levels and light in a shaded stream. Can J Fish Aquat Sci 47:2307-2314

> Hill WR, Boston HL, Steinman AD (1992) Grazers and nutrients simultaneously limit lotic primary production. Can J Fish Aquat Sci 49:504-512

Hillebrand H, Kahlert M (2002) Effect of grazing and water column nutrient supply on biomass and nutrient content of sediment microalgae. Aquat Bot 72:143-159

Hillebrand H, de Montepellier G, Liess A (2004) Effects of macrograzers and light on periphyton stoichiometry. Oikos 106:93-104

> Hixon MA, Brostoff MN (1996) Succesion and herbivory: effects of differential fish grazing on Hawaiian coral-reef algae. Ecol Monogr 66:67-90

Hughes AR, Jun Bando K, Rodriguez LF, Williams SL (2004) Relative effects of grazers and nutrients on seagrasses: a meta-analysis approach. Mar Ecol Prog Ser 282:87-99

Hunter RD, Russel-Hunter WD (1983) Bioenergetic and community changes in intertidal Aufwuchs grazed by Littorina littorea. Ecology 64:761-769

Hurd CL, Durante KM, Chia FS, Harrison PJ (1994) Effect of bryozoan colonisation on inorganic nitrogen acquisition by the kelps Agarum fimbriatum and Macrocystis intefolia. Mar Biol 121:167-173

Jaschinski S, Sommer U (2008a) Functional diversity of mesograzers in an eelgrass-epiphyte system. Mar Biol 154: $475-482$
Jaschinksi S, Sommer U (2008b) Top-down and bottom-up control in an epiphyte-eelgrass (Zostera marina L.) system. Oikos 117:754-762

> Kaehler S, Froneman PW (2002) Herbivore-mediated increase in the photosynthetic capacity of marine biofilms: indirect effects of changing microbial composition. Mar Ecol Prog Ser 234:15-22

Kahlert M, Baunsgaard MT (1999) Nutrient recycling-a strategy of a grazer community to overcome nutrient limitation. J N Am Benthol Soc 18:363-369

> Lamberti GA, Resh VH (1983) Stream periphyton and insect herbivores: an experimental study of grazing by a caddisfly population. Ecology 64:1124-1135

- Lamberti GA, Ashkenas LR, Gregory SV, Steinman AD (1987) Effects of three hervibores on periphyton communities in laboratory streams. J N Am Benthol Soc 6:92-104

Liess A, Olsson J, Quevedo M, Eklöv P, Vrede T, Hillebrand H (2006) Food web complexity affects stoichiometric and trophic interactions. Oikos 114:117-125

> Littler MM, Littler DS, Taylor PR (1995) Selective herbivore increases biomass of its prey: a chiton-coralline reefbuilding association. Ecology 76:1666-1681

Lorenzen OJ (1967) Determination of chlorophyll and phaeopigments: spectrophotometric equations. Limnol Oceanogr 12:343-346

McCormick PV, Stevenson RJ (1991) Grazer control of nutrient availability in the periphyton. Oecologia 86:287-291

Mulholland PJ, Steinman AD, Palumbo AV, Elwood JW, Kirschtel DB (1991) Role of nutrient recycling and herbivory in regulating periphyton communities in laboratory streams. Ecology 72:966-982

Nacken M, Reise K (2000) Effects of herbivorous birds on intertidal seagrass beds in the northern Wadden Sea. Helgol Mar Res 54:87-94

Penhale P (1977) Macrophyte-epiphyte biomass and productivity in an eelgrass (Zostera marina L.) community. J Exp Mar Biol Ecol 26:211-224

> Probyn TA, Chapman ARO (1983) Summer growth of Chordaria flagelliformis (O. F. Muell.) C. Ag. Physiological strategies in a nutrient stressed environment. J Exp Mar Biol Ecol 73:243-271

Rosemond AD, Mulholland PJ, Elwood JW (1993) Top-down and bottom-up control of stream periphyton: effects of nutrients and herbivores. Ecology 74:1264-1280

Short FT, Coles RG, Short CA (eds) (2001) Global seagrass research methods. Elsevier, Amsterdam

> Sommer U (1999) The impact of herbivore type and grazing pressure on benthic microalgae diversity. Ecol Lett 2: 65-69

> Sterner RW (1986) Herbivores' direct and indirect effects on algal populations. Science 231:605-607

Taylor RB, Rees TAV (1998) Excretory products of mobile epifauna as nitrogen source for seaweeds. Limnol Oceanogr 43:600-606

- Valentine JF, Heck KL Jr, Busby J (1997) Experimental evidence that herbivory increases shoot density and productivity in a subtropical turtlegrass (Thalassia testudinum) meadow. Oecologia 112:193-200

van Montfrans J, Orth RJ, Vay SA (1982) Prelimilary studies of grazing by Bittium varium on eelgrass periphyton. Aquat Bot 14:75-89

Williamson JE, Rees TAV (1994) Nutritional interaction in alga-barnacle associations. Oecologia 99:16-20 